\title{
Rome and Persia in the Middle of the Third Century AD (230-266)
}

\author{
Lukas de Blois
}

From about 230 to $266 \mathrm{AD}$ a momentous struggle was going on at the eastern borders of the Roman Empire. The Persian wars waged by Severus Alexander (231-234), Gordian III (242-244), and the emperors and vassal kings who reigned between $25^{2}$ and 268 should be counted among the main causes of the problems Roman emperors had to face in the middle decades of the third century. The issues I want to discuss in this contribution are: why did this long and dangerous conflict arise, what was the character and aim of Persian actions, and what was the impact of these Persian wars on Roman imperial power?

In 8o.3.1-4 Cassius Dio, writing about Severus Alexander's later years, tells us:

The situation in Mesopotamia became still more alarming and inspired a more genuine fear in all, not merely the people in Rome, but the rest of mankind as well. For Artaxerxes (i.e. Ardashir I, AD 226-241), a Persian, after conquering the Parthians in three battles and killing their king, Artabanus, made a campaign against Hatra, in the endeavour to capture it as a base for attacking the Romans. He actually did make a breach in the wall, but when he lost a good many soldiers through an embuscade, he moved against Media. Of this country, as also of Parthia, he acquired no small portion, partly by force and partly by intimidation, and then marched against Armenia. Here he suffered a reverse at the hands of the natives, some Medes, and the sons of Artabanus, and either fled, as some say, or, as others assert, retired to prepare a larger expedition. He accordingly became a source of fear to us; for he was encamped with a large army so as to threaten not only Mesopotamia but also Syria, and he boasted that he would win back everything that the ancient Persians had once held, as far as the Greek Sea, claiming that all this was his rightful inheritance from his forefathers. The danger lies not in the fact that he seems to be of any particular consequence in himself, but rather in the 
fact that our armies are in such a state that some of the troops are actually joining him and others are refusing to defend themselves. ${ }^{1}$

This is no report from hindsight, by a later author who knew what Persian wars could be like. It is, rather, a chapter written by a contemporary senator, who was well acquainted with the emperor Severus Alexander. ${ }^{2}$ In this passage there are two important interconnected issues: Ardashir and his growing army are a source of fear to Rome as soon as they come near Syria and Mesopotamia, and Ardashir wants to reconquer parts of the Roman Empire that had once belonged to the Achaemenid Empire. ${ }^{3}$ Apparently, Dio's perception of the rising conflict is that Persia was the agressor. At the end of this passage Dio adds that the Persians were of no great consequence in themselves, but had a good chance to win because the quality of the Roman army of the East was very poor, which fits neatly with Dio's negative attitude towards the Roman soldiery, but also testifies to his underestimating of quantity and quality of the forces the Sassanians could mobilize. ${ }^{4}$

Another contemporary author, Herodian, tells us in 6.2.1:

... in his (i.e. Alexander's) tenth year unexpected letters came from the governors of Syria and Mesopotamia with information that Artaxerxes (i.e. Ardashir), king of the Persians, had defeated the Parthians, broken up their eastern kingdom and killed Artabanus, the previous great king who wore the double crown. He had also gained complete control over the neighbouring barbarians and reduced them to tributary status. He was causing unrest by refusing to be contained by the river Tigris and was crossing the banks which were the boundary of the Roman empire. Mesopotamia was overrun and Syria threatened.

1 Cassius Dio 80. 3-4. Translations of passages in the works of Cassius Dio and Herodian were borrowed from editions in the Loeb Classical Library.

2 See Cassius Dio 80. 5. 1: Severus Alexander honored Dio in various ways, especially by appointing him to be consul for the second time, as his colleague, and taking upon himself personally the responsibility of meeting the expenditures of Dio's second consulship.

3 The first Sasanian king. He put down the Parthian Arsacid dynasty between 224 and 226, and ruled from those years up to 241. See Josef Wiesehöfer, 'Das Reich der Sasaniden', in KlausPeter Johne, Udo Hartmann and Thomas Gerhardt (eds.), Die Zeit der Soldatenkaiser (Berlin 2008), I, 536-537.

4 Lukas de Blois, 'Emperor and Empire in the Works of Greek-speaking Authors of the Third Century A.D.', in W. Haase and H. Temporini (eds.), Aufstieg und Niedergang der Römischen Welt II 34, 4 (Berlin/New York 1998), 3411-3412. 
This looks like a summary of events, in which details have been left out, and which focuses upon a later phase of the struggle, when mutual distrust had resulted in open violence. In 6.2.2 the author says:

Believing that the entire mainland facing Europe contained by the Aegean Sea and the Propontis Gulf ... belonged to him by ancestral right, he was intending to recover it for the Persian empire.

Severus Alexander, unlike Dio not underestimating the Persian threat, seems to have reacted in full force. If we may believe Herodian 6.3.1, in 230-231 the whole Roman Empire was in a state of complete upheaval because the emperor and his helpers were gathering together a large army to match the reported size of the barbarian invasion. From Italy and all the Roman provinces special levies were recruited for the army.

Aside from Dio and Herodian there is not much evidence that Ardashir and his successor Shapur I (241-270) wished to conquer large parts of the Roman Empire, as far as the Aegean Sea. The only indication one could think of is the composition of the reliefs at Naqsh-i-Rustam, where Sassanian representations were carved into the rock beneath much older Achaemenid royal tombs and sculptures. ${ }^{5}$ Continuity may be suggested here. Still, it is not very plausible that the first Sassanian king had such far-reaching intentions. About 230 Ardashir was still busy to stabilize his power in his own realm. In a number of petty wars he was removing many local princes who were anyhow related to the Arsacid family, appointing new satraps and viceroys in their places, quite a few of whom were related to himself. ${ }^{6}$ Dio's remark about Persian pretensions to restore the old Achaemenid Empire sounds like Roman war propaganda. ${ }^{7}$

5 See David S. Potter, Prophecy and History in the Crisis of the Roman Empire (Oxford 1990), 372376; Josef Wiesehöfer, Das antike Persien von 550 v.Chr. bis 650 n.Chr. (Munich/Zürich 1994), 51-52, 208, and 215-216; Udo Hartmann, Das Palmyrenische Teilreich (Stuttgart 2001), 67.

6 See Hartmann 2001, op. cit. (n. 5), 65; David S. Potter, The Roman Empire at Bay, A.D. $180-$ 395 (London/New York 2004), 222; Richard N. Frye, 'The Sassanians', in Cambridge Ancient History XII ${ }^{2}$ (Cambridge 2005), 465-467; Wiesehöfer 2008, op. cit. (n. 3), 536. Ardashir not only defeated the Parthians and many local rulers, but — unlike his Parthian predecessorsthe Sassanian ruler removed many local princes and appointed members of his own family in their places, as his lieutenants. See Frye, op. cit. 467.

7 See Cassius Dio 80. 4. 1; Herodian 6. 2. 2; Zonaras 12. 15. That the Persians wanted to restore the old Achaemenid empire was a Roman propagandistic view; the aims of the Persian king were much more restricted. See John Drinkwater, "The 'catastrophe' of 260 ", Rivista storica dell'antichità 19 (1989), 126; Potter 1990, op. cit. (n. 5), 372-376; Potter 2004, op. cit. (n. 6), 223-225; Erich Kettenhofen, 'Einige Überlegungen zur sasanidischen Politik gegenüber Rom 
Ardashir's strategy was quite different: he tried to eliminate Arsacid remnants in Armenia, and conquer places such as Hatra, which invading Romans-or Arsacids from Armenia - would be needing as a base and storage facility, if they should set out to conquer Southern Mesopotamia, the Parthian and Persian Empire's main agrarian and trading area, which was their most important tax territory. ${ }^{8}$ According to Stefan Hauser, Ardashir was just attempting to restore the Arsacid Parthian Empire as it had been before the wars of Lucius Verus and Septimius Severus. ${ }^{9}$ This may very well be right, but it cannot be proven. In his article in the same volume, Benjamin Isaac still adheres to the opinion that Persian demands were consistently more militant than the Parthian ones had been. ${ }^{10}$

The main reason for the ensuing war between the Romans and Persians is explicitly mentioned by Dio: distrust among Roman rulers and their governors about the growing military force that Ardashir was gathering. On the Persian side there may have been a fear of Romans assisting the Arsacids, and of Roman outposts being very near Southern Mesopotamia, their most important tax territory. Among these outposts were the caravan city of Palmyra, with its string of forts along the Euphrates, ${ }^{11}$ Dura Europos, a stronghold founded about 303 BC by the Seleucids on the intersection of an east-west trade route and the trade route along the Euphrates, ${ }^{12}$ and from about 229 also Hatra, which had gone over

im 3. Jh.n.Chr., in E. Dabrowa (ed.), The Roman and Byzantine Army in the East (Krakow 1994), 99-108; idem, 'Die Einforderung der achaimenidischen Territorien durch die Sasaniden-eine Bilanz', in S. Kurz (ed.), Festschrift Iradj Khalifeh-Soltani zum 65. Geburtstag (Aachen 2002), 50-75; Hartmann 2001, op. cit. (n. 5), 67; and Karin MosigWalburg, Römer und Perser vom 3. Jh. bis zum Jahr 363 n. Chr. (Gutenberg 2009), 19-23.

8 On the Arsacids in Armenia after 224 see C.S. Lightfoot, 'Armenia and the Eastern Marches', in Cambridge Ancient History XII ${ }^{2}$ (Cambridge 2005), 491-493; Erich Kettenhofen, 'Die kaukasischen Reiche', in Klaus-Peter Johne, Udo Hartmann and Thomas Gerhardt (eds.), Die Zeit der Soldatenkaiser (Berlin 2008), I, 480-483.

Stefan R. Hauser, 'Where is the Man of Hadr, who once Built and Taxed the Land by the Tigris and Chaboras? On the Significance of the Final Siege of Hatra', in Lucinda Dirven (ed.), Hatra. Politics, Culture and Religion between Parthia and Rome (Stuttgart 2013), 139. Benjamin Isaac, 'Hatra against Rome and Persia: From Success to Destruction', in Lucinda Dirven (ed.), Hatra. Politics, Culture and Religion between Parthia and Rome (Stuttgart 2013), 28.

11 On Palmyra and its outposts see Raphaela Drexhage, Untersuchungen zum römischen Osthandel (Bonn 1988), 61-86; Hartmann 2001, op. cit. (n. 5), 52-8; Maurice Sartre, ,The Arabs and the Desert Peoples', in Cambridge Ancient History $\mathrm{XII}^{2}$ (Cambridge 2005), 511-514.

12 On Dura-Europos and the praetentura (military district) of the Middle Euphrates, see Denis Feissel and Jean Gascou, 'Documents d'archives romains inédits du Moyen 
to the Roman side, probably because it had been (unsuccessfully) attacked by the Persians..$^{13}$ There are traces of Roman military presence at Hatra in 235 and 238 , as indicated by three Latin inscriptions. ${ }^{14}$ The Persians may also have been interested in trading centres such as Nisibis. That the Persian leaders thought along these lines is indicated by the persistency with which they kept attacking Hatra, Dura, and Nisibis. Hatra they took and destroyed between 12 April 240 and 1 April 241, after a preceding unsuccessful siege in 229. The Persians made a tremendous effort. The most extended siege works known in the Near East were recently detected at Hatra. Stefan Hauser and David Tucker, the excavators, date the structures to the conquest by Ardashir I in AD 240/241. ${ }^{15}$ Dura was taken by the Persians in 256 , after preceding attacks in 239 and $252 / 253 .{ }^{16}$ Nisibis was a bone of contention from the reign of Gordian III until 262, when it was destroyed by the Palmyrene prince Odaenathus, the emperor Gallienus'

Euphrate (III ${ }^{\mathrm{e}}$ siècle après J.-C.)', Journal des Savants (1995), 102-103. See also Fergus Millar, The Roman Near East, ${ }_{1} B C-A D 337$ (London/Cambridge, MA 1993), 131-133.

13 On Ardashir attacking Hatra in 229 (or even 228) see Cassius Dio 80. 3. 2.

$14 A E$ 1958, 238-240. See Erich Kettenhofen, Die römisch-persischen Kriege des 3.Jahrhunderts n. Chr: nach der Inschrift Šāhpuhrs I. an der Ka'be-ye Zartošt (ک̌KZ) (Wiesbaden 1982), 21; Isaac 2013, op. cit. (n. 10), 27, and Hauser 2013, op. cit. (n. 9), 131. Benjamin Isaac is dating the Roman presence at Hatra too late, to $238-240$. Roman military had not yet been at Hatra in 229, when Ardashir had vainly attacked the stronghold, but they were there about 235 .

15 <http://www.dainst.org/sites/default/files/media/abteilungen/orient/redaktion/zora2 hauser_-_tucker.pdf?ft=all> (10 December 2013). See Hauser 2013, op. cit. (n. 9), 122-133. That Hatra was taken between 12 April 240 and the first of April 241 is attested by Codex Manichaeus Coloniensis 18.1-16, ed. Koenen \& Römer, 10-12. See Kettenhofen 1982, op. cit. (n. 14), 20; Hauser 2013, op. cit. (n. 9), 121.

16 See $S E G$ VII 1934, 743b, ll. 17-19, a Greek graffito from the house of Nebuchelus at Dura, which tells us that on the 3oth day of the month of Xandikos of the year $55^{\circ}$ (Seleucid era, equivalent to 20 April 239) the Persians descended upon Dura-Europos (without taking it). See Ulrich Huttner, 'Von Maximinus Thrax bis Aemilianus', in Klaus-Peter Johne, Udo Hartmann and Thomas Gerhardt (eds.), Die Zeit der Soldatenkaiser (Berlin 2008), I, 182 n. 187 (Persian attack in 239), 219 with n. 523 (Persians possibly in Dura in 253). On Dura being taken in 256 see Kettenhofen 1982, op. cit. (n. 14), 77-83; Jean Gascou, 'Unités administratives locales et fonctionnaires romains. Les données des nouveaux papyrus du Moyen Euphrate et d'Arabie', in Werner Eck (ed.), Lokale Autonomie und römische Ordnungsmacht in den kaiserzeitlichen Provinzen vom 1. Bis 3. Jh. (Munich 1999), 71; Andreas Goltz and Udo Hartmann, 'Valerianus und Gallienus', in Klaus-Peter Johne, Udo Hartmann and Thomas Gerhardt (eds.), Die Zeit der Soldatenkaiser (Berlin 2008), I, 237 (Dura taken and destroyed in 256). 
virtual viceroy in the East, allegedly because it had become pro-Persian. ${ }^{17}$ The first time the Persians took Nisibis and Carrhae cannot be dated to the reign of Maximinus Thrax, but must have followed the demise of Hatra, and elicited Gordian's great campaign of $242-244 .{ }^{18}$

That conquering and occupying the eastern Roman provinces that were situated between Mesopotamia and the Aegean Sea was not the Persian aim of war is also indicated by the way in which Persian armies campaigned in $25^{2-253}$ and 259-261. After initial victories, in 253 at Barbalissos at the northward bend in the river Euphrates, and in 260 at Edessa, where they took the Roman emperor Valerian prisoner, they spread out in groups to loot and plunder. As Fergus Millar remarks: "Even in the record of his victories put up by Shapur I, the second Sasanid king, makes quite clear that they were simply destructive raids."19 The Persians tried to take home valuables, and deported people without permanently occupying strategic places. In this way they became vulnerable to counter-attacks by remaining Roman units, and by troops of vassal princes, such as Uranius Antoninus of Emesa in 253, and the Palmyrene prince Odaenathus in $260 .^{20}$

The impact of the Persian wars of the mid-third century on Roman imperial power was tremendous. First of all, Roman emperors regularly lost a good deal of their military manpower. Three telling examples.

Having tried to negotiate, though in vain, Alexander and his advisors assembled a large army and departed to the East. He recruited new soldiers, as we have seen, but undoubtedly he took with him as well most of the garrison of Italy and detachments from frontier legions. The idea was to attack Ardashir with three armies, one in the North, through the mountains into Media Atropatene, another one in the South, along the river Euphrates and via the allied Palmyrene strongholds that could provide food and shelter, and the main force with the emperor in the middle, in Northern Mesopotamia. The northern forces were successful, but not decisively so. The central army was too slow,

17 On Nisibis as a bone of contention since the reign of Gordian III see Huttner 2008, op. cit. (n. 16), 178, 182 n. 187, and 214; Goltz and Hartmann 2008, op. cit. (n. 16), 353 (Nisibis in 262 destroyed by Odaenathus; cf. Zosimus 1. 39. 1); Hauser 2013, op. cit. (n. 9), 137.

18 Hauser 2013, op. cit. (n. 9), 137-138.

19 Millar 1993, op. cit. (n. 12), 148. See RGDS 5-9, and 12-15.

20 Uranius Antoninus: H.R. Baldus, Uranius Antoninus of Emesa. Münzprägung und Geschichte (Bonn 1971); Kettenhofen 1982, op. cit. (n. 14), 70-76; Potter 1990, op. cit. (n. 5), 323-328; idem, 2004, op. cit. (n. 6), 249-250, referring to Oracula Sibyllina 13. 147-154 and Malalas 296; Huttner 2008, op. cit. (n. 16), 220-221. Odaenathus in 26o: Festus 23; Orosius 7. 22. 12; Oracula Sibyllina 13. 164-171. See Potter 1990, op. cit. (n. 5), 341-347; Hartmann 2001 138-9; Mosig-Walburg 2009, op. cit. (n. 7), 49-50. 
and thus gave the Persians the opportunity to concentrate first on the southern Roman wing, which was annihilated, and then to fight the main Roman force. A big battle between Alexander and the Persians resulted in a costly draw, and subsequently the emperor and many of his men fell ill and retreated to Antioch to recover. The northern army was summoned back to Syria and sustained heavy losses in the mountainous area it had to cross. Remarkably enough, Ardashir did not follow up his successes, probably because he had lost a good deal of his forces as well. If we may believe Herodian, he retreated, accepted a kind of armistice, which lasted three or four years, and disbanded his army (Herodian 6.6.4-6). ${ }^{21}$

In the Res Gestae Divi Saporis (RGDS), the great inscription of Shapur I $(241-270)$ on the ka'aba at Naqsh-i-Rustam, ${ }^{22}$ we are told that Gordian III in 242 took a sizeable army with him to the East. He, or rather, his advisors, probably wanted to conquer the Persians once and for all. Next to detachments from the Rhine ad Danube armies and troops from Italy, his force seems to have comprised quite a few Germans and other former northern enemies. The RGDS speaks of "a force from the Goth and German realms." Gordian's army was victorious at Rhesaena, in 243 , and took back Nisibis and some other places, but was badly beaten at Misiche at the Euphrates, right at the point where the Roman army would have entered the fertile Southern Mesopotamia. This must have taken quite a few lives. ${ }^{23}$ In 252 , another round of Persian wars began. In RGDS $4-5$ we read:

21 On Alexander's eastern campaign see Herodian 6. 5-6; Zonaras 12. 15. See Potter 1990, op. cit. (n. 5), 378-380; Maurice Sartre, The Middle East under Rome (London/Cambridge, MA 2005), 343; Brian Campbell, 'The Severan Dynasty', in Cambridge Ancient History XII ${ }^{2}$ (Cambridge 2005), 25-26; Michel Christol, L'empire romain du IIIe siècle, 192-325 apr. J.-C., 2nd ed. (Paris 2006), 73-74.

22 This inscription starts with Shapur I's accession to the throne and culminates in Valerian's demise in AD 26o. Fergus Millar, 'Government and Diplomacy in the Roman Empire during the First Three Centuries', in H.M. Cotton and G.M. Rogers (eds.), Government, Society and Culture in the Roman Empire (Chapel Hill NC/London 2004), vol. 2, 197, says: "As such, it (=RGDS) represents very accurately the drastic nature of the third-century crisis of the Empire. In this phase of the history of the Roman Empire an emperor may be captured in person in the field, be killed in battle, have to treat for terms, or pay his enemy money to obtain peace."

23 RGDS 3-4: "When at first we had become established in the Empire, Gordian Caesar raised in all of the Roman Empire a force from the Goth and German realms and marched on Babylonia against the Empire of Iran and against us. On the border of Babylonia at Misiche, a great frontal battle occurred. Gordian Caesar was killed and the Roman force was destroyed. And the Romans made Philip Caesar. Then Philip Caesar came to us for terms, and to ransom their lives, gave us 500,00o denars (probably aurei), and became 
And Caesar lied again and did wrong to Armenia (probably helping the Arsacid remnants surviving there). Then we (= the Persian king Shapur I and his army) attacked the Roman Empire and annihilated at Barbalissos a Roman force of 60,000 , and Syria and the environs of Syria we burned, ruined and pillaged all. In one campaign we conquered of the Roman Empire fortresses and towns (then follows a catalogue of conquered places, among them Antioch).

In 253 Shapur I defeated the Roman forces of the East at Barbalissos, plundered Syria, took Antioch, and went back home, probably because Roman remnants and vassals had caused a lot of trouble for his army. In the same year, 253, another Persian force conquered Armenia. ${ }^{24}$ In 256 or 257 Shapur at last conquered Dura-Europos. ${ }^{25}$ In 259-26o the Roman emperor Valerian fought the Persians in a long campaign. Like Severus Alexander before him, he lost

tributary to us" (transl. Richard N. Frye, The History of Ancient Iran [Munich, 1983], appendix 4, 371-372). On Gordian's campaign see Millar 1993, op. cit. (n. 12), 153-154. On Gordian's defeat and death see Oracula Sybillina 13. 13-20, with Potter 1990, op. cit. (n. 5), 36 and 202-211, and Ammianus Marcellinus 23.5.17: redissetque pari splendore iunior Gordianus, cuius monumentum nunc vidimus honorate, apud Resainan superato fugatoque rege Persarum, ni factione Philippi praefecti praetorio sceleste iuvantibus paucis in hoc, ubi sepultus est, loco vulnere impio cecidisset (... the younger Gordianus, whose monument we just now looked upon with reverence, would have come back with equal glory [to Trajan's, Verus', and Severus'], after vanquishing the Persian king and putting him to flight at Resaina, had he not been struck down by an impious wound inflicted by the faction of Philippus, the praetorian prefect, and a few wicked accomplices, in the very place where he now lies buried). More evidence is mentioned by Christian Körner, Philippus Arabs. Ein Soldatenkaiser in der Tradition des antoninisch-severischen Prinzipats (Berlin/ New York 2002), 75-85. On the many losses Gordian's army had to sustain see Richard P. Duncan-Jones, 'Economic Change and the Transition to Late Antiquity', in Simon Swain and Mark Edwards (eds.), Approaching Late Antiquity. The Transition from Early to Late Empire (Oxford 2004), 21-22.

24 See Ammianus Marcellinus 23. 5. 3; Oracula Sibyllina 13. 89-136; Zosimus 1. 27. 2, and the sources mentioned by M.H. Dodgeon and S.N.C. Lieu, The Roman Near Eastern frontier and the Persian wars, A.D. 226-363 (London/New York, 2nd ed., 1994), 49-55. See Kettenhofen 1982, op. cit. (n. 14), 38-43 (Armenia, and Hormizd's campaign, cf. pp. 83-87); 50-52 (rapid Persian march along the Euphrates, passing by of fortresses such as Dura); 53 (battle at Barbalissos); 56-59 (Persians plundering); 59-65 (fall of Antioch, 253). See also Millar 1993, op. cit. (n. 12), 159-162; Potter 2004, op. cit. (n. 6), 248-250; Christol 2006, op. cit. (n. 21), 126-127.

25 Kettenhofen 1982, op. cit. (n. 14), 77-83; D. MacDonald, 'Dating the Fall of Dura-Europos', Historia 35 (1986), 45; Millar 1993, op. cit. (n. 12), 162-163. 
many soldiers to disease. In 260 , he realized that he had become too weak to beat the Persians, amassed a lot of gold to buy them off, but in the end engaged the Persians near Edessa to relieve that important stronghold. Valerian was defeated and taken prisoner. The Persians again invaded the Roman empire, through Syria and a more northerly route. They spread out to plunder, and thus again became vulnerable to counter-attacks, in this case by Roman remnants under Ballista and the troops of the Palmyrene prince Odaenathus, a Roman ally. The Persians had to leave the Roman provinces, and had in 262 and 266 to sustain two invasions by Odaenathus, who commanded not only his own forces, but also remaining Roman units. ${ }^{26}$ Again many Roman soldiers' lives had been lost, and not only among the units of the eastern armies. An inscription proves that Valerian was at Cologne in 257, together with his son and co-emperor Gallienus. ${ }^{27}$ Starting from Cologne, he probably went all along the Rhine and Danube border regions to the East, assembling vexillationes from the legions, auxilia, and Germanic and other foreign allies on his way. The Persian king Shapur's Res Gestae Divi Saporis indicates that Valerian's army consisted of detachments and units from almost every part of the Roman empire, with Germanic allies. ${ }^{28}$ A good part of this army died in the East, either through the plague, which was rampant again since $25^{2},{ }^{29}$ other diseases, or actual warfare, leaving behind many open spaces along the Rhine and Danube. From the Vindolanda tablets we know how many soldiers and officers were regularly absent from their stations in a relatively peaceful period, and under Valerian and Gallienus, it must have been much worse. Furthermore, Gallienus concentrated many vexillationes and cavalry units in his new mobile army, with which he tracked down and annihilated groups of invaders who had dispersed

26 On the campaigns of 259-26o and Odaenathus' raids into the Persian Empire see Oracula Sibyllina 13. 155-171; Aurelius Victor, Caesares 32. 5; Eutropius 9. 7; Petrus Patricius, in Karl Otfried Müller, Fragmenta Historicorum Graecorum Iv (Paris 1851), 187, frg 9; Zosimus 1. 36. 1-2 and 1. 39. 1-2; Zonaras 12. 23; Syncellus 466. See Kettenhofen 1982, op. cit. (n. 14), 97-126; Millar 1993, op. cit. (n. 12), 166-169; Goltz and Hartmann 2008, op. cit. (n. 16), 247-254, 257-62, 271.

27 Charlotte Roueché, Aphrodisias in Late Antiquity (London 1989), 4-8, nr. 1, a fragmentary letter of Valerian and Gallienus written from Cologne, dated 23 August 257. See Millar 1993, op. cit. (n. 12), 164 n. 22; Goltz and Hartmann, 'Valerianus und Gallienus', 238 n. 84.

28 RGDS 9-11.

29 On the plague of $25^{2}$ and its effects see Eutropius 9. 5; Eusebius HE 7. 21-22; Aurelius Victor, Caesares 30. 2; Orosius 7. 21. 5; 7. 27. 10; Zosimus 1. 26. 2, and Zonaras 12. 21. In Oracula Sibyllina 13.106 it is briefly mentioned. 
their forces to plunder. ${ }^{30}$ Those detachments seldom returned to their original stations.

Another effect of the Persian wars of the mid-third century was the undermining of the dominant imperial victory-ideology. As Carlos Noreña makes clear, Victoria always stood as the central imperial ideal around which all others, such as peace, stability, prosperity, and felicitas saeculi circled. Noreña shows that the centrality of Victory is clear from numismatic evidence. ${ }^{31} \mathrm{We}$ might add that it is one of very few messages from imperial coinage that is also massively found on local coins, in various Greek-speaking provinces, and in dating formulas of papyrus texts from Egypt, ${ }^{32}$ and not just on imperial coinage. If the Romans' eternal potential for victory was put into jeopardy, a loss of authority, resulting in usurpations and self-help, was to be expected, and did actually come about. And put into jeopardy it was. Severus Alexander's expedition resulted in a draw, and his soldiers resented his lack of success. But

30 See Alan K. Bowman and J. David Thomas, The Vindolanda Writing-Tablets (Tabulae Vindolandenses II) (London 1994), 90-98, nr. 154 (strength report of the First Cohort of Tungrians), and pp. 98-100, nr. 155. Nr 154 (esp. p. 92) shows that 119 out of $75^{2}$ men were not involved in any border duty, and 337 were stationed at another post, at Corbridge (Coria). The 337 doing duty at Corbridge did not weaken frontier defenses. In the period of crisis under Gallienus, however, sizeable percentages of northern frontier units must have disappeared to the East or to Gallienus' new mobile army, not to another frontier station. On Gallienus' new army, consisting of cavalry and infantry detachments, see Michel Christol, 'La carrière de Traianus Mucianus et l'origine des protectores', Chiron 7 (1977), 393-408.; H.-G. Simon, 'Die Reform der Reiterei unter Kaiser Gallien', in W. Eck, H. Galsterer and H. Wolff (eds.), Studien zur antiken Sozialgeschichte. Festschrift F. Vittinghoff(Vienna/ Cologne 1980), 435-451; Martijn Nicasie, Twilight of Empire. The Roman Army from the Reign of Diocletian until the Battle of Adrianople (Amsterdam 1998), 36-37; Pierre Cosme, L'armée romaine (Paris 2009), 212-215.

31 Carlos F. Noreña, Imperial Ideals in the Roman West (Cambridge 2011), 77-82 (Virtus Augusti), 109, and 147-165 (victory ideology on imperial coins). Cf. Erika Manders, Coining Images of Power. Patterns in the Representation of Roman Emperors on Imperial Coinage (Leiden/Boston 2012), 77-87.

32 On victory-symbols on local coinage see W.H. Waddington, E. Babelon and Th. Reinach, Recueil général des monnaies grecques d'Asie Mineure (Paris 1904/1912), 272-639; idem (Paris 1925), 45, 95, 161; R. Ziegler, Kaiser, Heer und städtisches Geld. Untersuchungen zur Münzprägung von Anazarbos und anderer ostkilikischen Städte (Vienna 1993), 272-275, 288, 317; K. Emmeth, Alexandrian Coins (Lodi WI 2001), 123-206; K. Butcher, Coinage in Roman Syria. Northern Syria, 64 B.C.-A.D. 253 (London 2004), 380-473 (catalogue). On the epithet anikètos in imperial titulature in papyrus texts in the third century AD, see Janneke de Jong, Emperors in Egypt. The Representation and Perception of Roman Imperial Power in Greek Papyrus Texts from Egypt, AD 193-284 (diss. Nijmegen 2006), 107-110. 
Gordian III and Valerian lost great battles, and died, or were taken prisoner. The bad thing was that all three emperors had assembled large armies, thus creating great expectations about their imminent successes.

Thirdly, the Persian wars of the mid-third century had a strong impact on imperial finances, and strained imperial infrastructures. Marching armies cost more than standing forces that could produce something, and were regular customers, in a given place. Under Septimius Severus, Caracalla, Gordian III, and Philip, so well before the intense military activity of the period 249-284, villagers from Euhippe (Asia), Takina (Phrygia), Skaptopare (Thrace), Aragua (Asia), and some other places in the neighbourhood of military transit routes complained to the emperors, telling them that soldiers turning off the main roads had been harassing them, and that military avarice and misbehavior had brought them into misery and bankruptcy, which would ultimately lead to anachoresis (flight from the land) and lower tax returns from their regions. ${ }^{33}$ Such complaints suggest that foodstuffs and commodities stored in fortified warehouses and towns along the roads were not sufficient to keep all marching soldiers satisfied, and that the military did not receive enough money to compensate villagers and townspeople, from whom the soldiers took what they needed.

Roman emperors such as Philip the Arabian and Valerian had, on top of their normal wartime expenses, to find money to pay off the Persians. After the Roman defeat at Misiche, in 244, and the death of Gordian III, Philip made his peace with the Persians, probably without permanently giving up any territory, but he had to recognize Persian primacy in Armenia, and to ransom many Roman soldiers (at a cost of 500,000 denarii). He also agreed to pay a probably annual tribute. ${ }^{34}$ Coming on top of subsidies to the Goths, who had received

33 See Tor Hauken, Petition and response. An epigraphic study of petitions to Roman emperors 181-249 (Bergen 1998), 203-214 (Tabala, AD 193), 215-216 (Euhippe, AD 211-213), 217-243 (Takina in Phrygia, AD 212-213), 74-139 (Skaptopara in Thrace, to Gordian III), 140-161 (Aragua in Phrygia, to Philip). See Stephen Mitchell, 'The Administration of Roman Asia from 133 BC to AD 250', in Werner Eck (ed.), Lokale Autonomie und römische Ordnungsmacht in den kaiserzeitlichen Provinzen vom 1. bis 3.Jh. (Munich 1999), 41; idem, Anatolia. Land, Men and Gods in Asia Minor I: the Celts and the impact of Roman rule (Oxford, 2nd ed., 2001), 228-235.

34 See RGDS 3-4: "On the border of Babylonia at Misikhe a great frontal battle occurred. Gordian Caesar was killed and the Roman force was destroyed. And the Romans made Philip Caesar. Then Philip Caesar came to us for terms, and to ransom their lives, gave us 500,000 denars, and became tributary to us. And for this reason we have renamed Misikhe Peroz-Shapur." Christol 2006, op. cit. (n. 21), 100, speaks of 500,000 'pièces d'or', and Huttner 2008, op. cit. (n. 16), 189-90 of aurei, but RGDS explicitly mentions denarii, 
money since 238, and the unavoidable donatives to the armed forces, which according to Zosimus 1.19.1 were large, ${ }^{35}$ this must have resulted in financial stress.

In 260 the emperor Valerian was beset by many problems. In one of the extant fragments of his work, Petrus Patricius tells us that in that year, Valerian, having lost many men to the plague, amassed an enormous amount of gold to buy off Shapur, because he now had too few troops left to beat his opponent. ${ }^{36}$ To be able to take over the plate needed to produce local coins, Valerian made an end to local coinage in the East. ${ }^{37}$

In conclusion. Were the Persian wars of the mid-third century just a trigger, the occasion that provoked a long imminent crisis in a potentially unstable administrative and social system? I am not so sure. Roman loss of face and setbacks in military personnel in the East were so tremendous, that they could easily induce other enemies, on the northern borders, to attack and plunder the empire in their turn, thus causing permanent and simultaneous threats and outright warfare along ever more frontiers. This was the main cause of crisis, not just a trigger.

and Shapur, the author, was certainly not in to modesty about his successes. On this peace treaty see Körner 2002, op. cit. (n. 23), 120-134.

35 This is one of the very few passages in his work where Zosimus says something of this kind.

36 Petrus Patricius, in: Müller, Fragmenta Historicorum Graecorum IV, p. 187, frg 9.

37 See Ziegler 1993, op. cit. (n. 32), 153-154; Butcher 2004, op. cit. (n. 32), 49, 261-264; Johannes Nollé, 'Bronzene Reflexe einer Krise. Das städtische Münzwesen Kleinasiens als Indikator von Phänomenen der Reichskrise des 3. Jahrhunderts und von zeitgenössischen Krisenempfinden', in Klaus-Peter Johne, Thomas Gerhardt and Udo Hartmann (eds.), Deleto paene imperio Romano. Transformationsprozesse des Römischen Reiches im 3. Jahrhundert und ihre Rezeption in der Neuzeit (Stuttgart 2006), 284. 